$$
\begin{gathered}
\text { SD } \\
143 \\
. A 5 \\
1922
\end{gathered}
$$




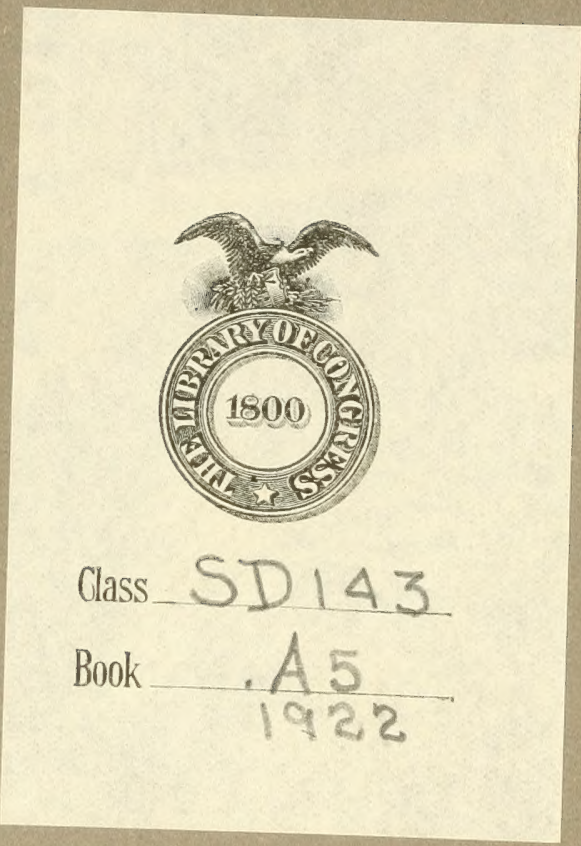




\section{DEPARTMENT OF AGRICULTURE}

\section{FORESTS AND FORESTRY IN THE UNITED STATES}

REPORT PREPARED FOR

THE COMMISSION OF THE UNITED STATES OF AMERICA TO THE BRAZIL CENTENNIAL EXPOSITION

$22-27449$

For Distribution at the Brazil Centennial Exposition

$$
\text { 1922-1923 }
$$





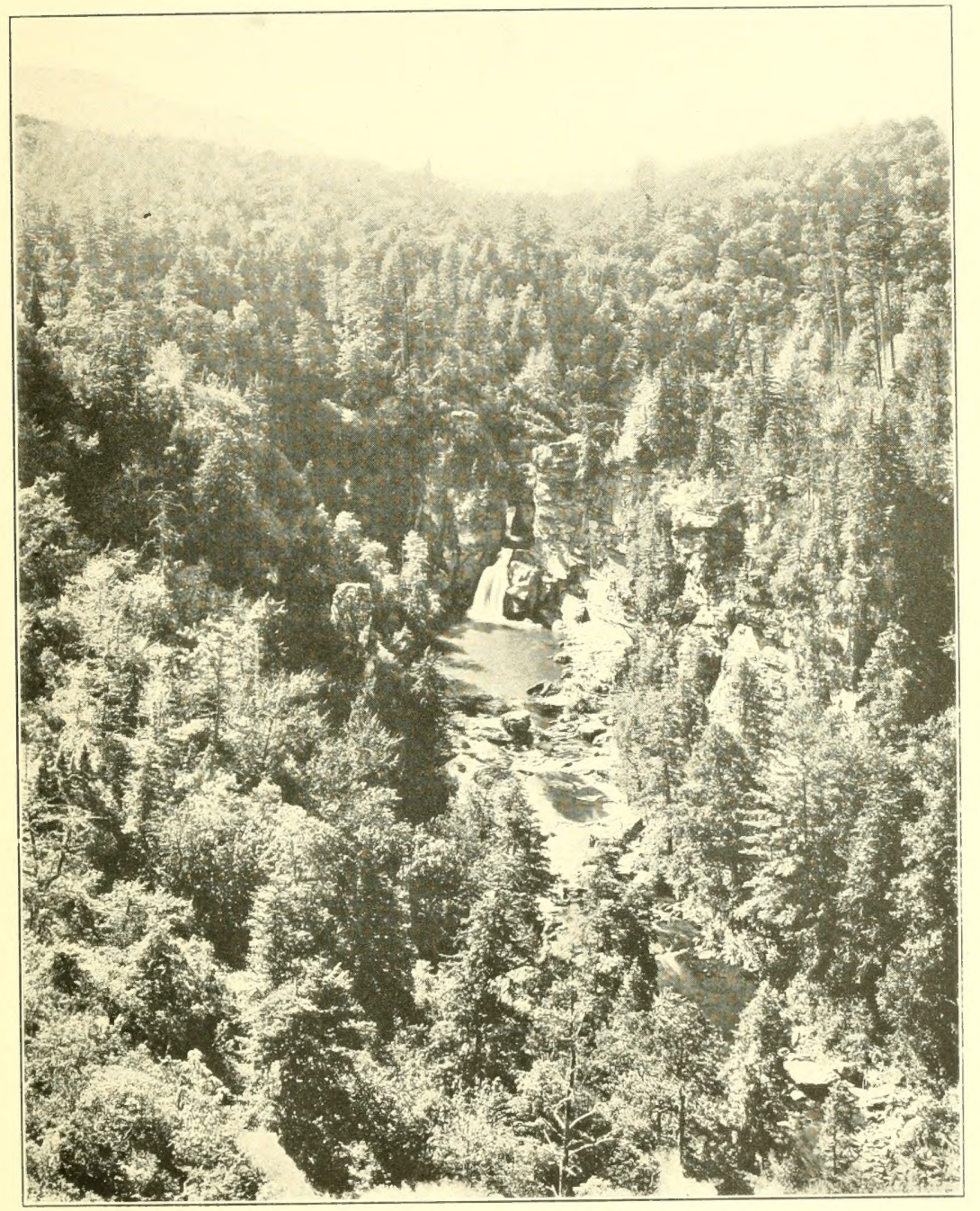





\title{
FORESTS AND FORESTRY IN THE UNITED STATES
}

\author{
$\nabla$ \\ Supplementing Exhibit \\ of the \\ UNITED STATES FOREST SERVICE \\ at the \\ BRAZIL CENTENNIAL EXPOSITION \\ Rio de Janeiro, Brazil \\ 1922-1923
}




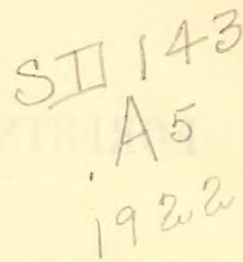

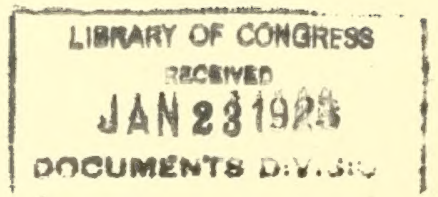




\section{FORESTS AND FORESTRY IN THE UNITED STATES.}

The present forest area of the United States is estimated at 463,000,000 acres, or something more than 723,000 square miles. ${ }^{1}$ This is a little more than one-half the original forest area of the country. The stand of timber is estimated roughly at 746 billion cubic feet, of which 485 billion cubic feet is saw timber and 26I billion cubic feet cordwood. Almost three-fourths of the saw timber is in the remaining virgin forests.

These remaining virgin forests are chiefly found in two widely separated regions, the South and far West, from which the United States is now drawing the bulk of its lumber cut. Together, they have 85 per cent of the total area still occupied by virgin growth, and 95 per cent of the remaining stand of virgin timber. The area of virgin growth in the far West is twice that in the South, with a stand in the ratio of $3 \frac{3}{4}$ to $\mathrm{I}$. But the lumber cut of the South, as compared with that of the far West, is in the ratio of 7 to 6 .

In the three hundred years that have passed since settlement began, the virgin forests of the United States have been the primary dependence of its inhabitants for their supplies of lumber. Only forty years ago intelligent men were wont to speak of the country's forest resources as inexhaustible. But it is now entirely clear that the needs of the nation require immediate and general provision for growing timber, as agricultural crops are grown. The lumber industry has been supported and is still mainly supported by the diminishing and retreating old-growth forests, now reduced to one-sixth their original size. A few years more will leave little but second growth in the pine forests of the South; and thereafter the requirements of the country for softwood lumber must be met from the western forests, involving heavy transportation costs, and from what has grown up on the cut-over lands in the older regions. These lands were first lumbered without provision for continuous production and then neglected. Left to take care of themselves as wild lands, and exposed to progressive devastation from recurrent forest fires, they have nevertheless grown a certain amount of timber, but for the most part of inferior quality.

In consequence the United States is entering on a period of timber shortage which is already being felt in the East, and which is bound

1 Knowledge of the forest resources of the United States is still incomplete in many particulars. For lack of fully satisfactory data, it is necessary to present statistics which are often approximations merely. Since in the nature of the case exact figures are not always possible, round numbers will be used throughout in this report. Ease of comparison as well as consistency of treatment will thus be gained. Readers desiring greater detail are referred to the Report of the Forest Service entitled "Timber Depletion, Lumber Prices, Lumber Exports, and Concentration of Timber Ownership," in which is incorporated the latest and fullest information available concerning the areas, stands, rates of growth, and current depletion of the forests in the various parts of the United States. 
to become more acute during the next half century. Forest management under which all timber lands not of sufficient value for agricultural use to warrant clearing shall be handled with a view to full employment of their capacity to grow wood continuously, has become of urgent public importance. While it can not wholly avert a timber shortage, it can both lessen its severity and limit its duration. The purpose of this report is to set forth what progress is being made toward a wiser handling of the country's forest resources - one of its greatest potential assets, and its sole dependence for meeting most of its requirements for wood, without large quantities of which its industrial life can not be maintained.

\section{ORIGINAL FORESTS OF THE UNITED STATES.}

The land area of the continental United States (exclusive of Alaska) is something under $3,000,000$ square miles. Approximately two-fifths of this area was originally forest-covered. The treeless prairie and plains region, which extends in a broad strip north and south from Canada to Mexico, in the west-central part of the country, separated these forests into two grand divisions. The eastern division was continuous and contained over I million square miles. The western division was broken and confined by dry climatic conditions, chiefly to the mountain ranges and high plateaus; its area was approximately 245,00o square miles.

Alaska, with a total area exceeding 590,000 square miles, had and still has a forest area the extent of which is imperfectly known, but which approximates 190,000 square miles. High mountain ranges, rising almost from the sea, separate the interior forests from those along the Pacific Coast. The latter form a long fringe of heavy and valuable timber, close to deep water, on the many islands and the mainland. A relatively mild climate and abundant precipitation here make possible a northward extension of the dense timber growth found along the coast of Oregon, Washington, and British Columbia. The coastal forests of Alaska cover 32,ooo square miles. Those of the interior grow under far more unfavorable climatic conditions, with subarctic temperatures and scant precipitation; they are therefore of an entirely different character. Their area has been variously estimated at from 125,000 to more than 230,000 square miles, but their importance as a source of timber supply for other than local purposes is at present nil, and so far as can now be foreseen, wili always be insignificant. For local use they will have very high value.

When settlement of the Atlantic Coast of North America began, the colonists from overseas were everywhere confronted with a deep and formidable forest that stretched from the water's edge, practically without a break, far into the remote and unknown interior. In the north, and again in the south, conifers predominated. Chief in importance among the northern conifers, or "softwoods," were white pine, spruce, and balsam fir; among the southern, several species of yellow pine, the woods of which are so similar that in commercial usage all are commonly classed together as "southern pine" or "southern yellow pine." Along 
the mountain ranges of the Appalachian system the northern conifers thrust far into the south, though confined to increasing altitudes as climatic and soil conditions enabled the broad-leafed species, or "hardwoods," to press them higher up the mountains. On the other hand, along the Atlantic Coast the southern pines made a counter advance as far north as to the Delaware capes.

West of the Appalachians, from the white pine forests of the Great Lalie's region to the southern pine forests that swept in a broad border along the coast of the Gulf of Mexico, the hardwoods held possession of a great area. Its westward limit was the prairies, which it skirted as far south as the Rio Grande. Eastward the same hardwood forest continued through the partial barrier of the mountains, where the northern softwoods held the higher elevations, and out toward the Atlantic coastal plain.

On a broad intermediate belt between the hardwood and the sonthern pine forest, pines and hardwoods contended for possession in a mixed forest. The southern pine forest proper occupied most of the coastal plain from the mouth of Chesapeake Bay to the Trinity River, in what is now east Texas. The mixed forest, broadly speaking, paralleled it, running from tidewater on and above the Chesapeake southwestward and then, north of the Gulf of Mexico, westward. Similarly, hardwoods and the northern sof twoods contested possession with each other through much of the Great Lakes region, and eastward from the Lakes to the ocean.

Thus the forests of the eastern United States afforded vast supplies of both softwoods and hardwoods. Softwood forests are, the world over, the main reliance for lumber for structural and general purposes. The liardwoods, on the other hand, furnish many woods of peculiar adaptability for special purposes. The hardwood forests of the United States are almost unique among temperate hardwoods in their richness in species that produce material of high utility along varied lines. The softwond and the hardwood forests of the country lave both been indispensable to its industrial development.

In the East the total forest area of more than $1,000,000$ square miles was made up of something like 400,000 square miles of snftwood forest, 500,000 square miles of hardwood forest, and I50,000 square miles of mixed softwoods and hardwoods. The northern softwood forests included two subdivisions. Spruce and fir were the chicf species in one of them; in the other, three species of pine, of which white pine was by far the most important. The spruce-fir forest covered perhaps $6_{5}, 000$ square miles in the northernmost part of what is now the eastern Lnited States and on the upper slopes of the mountains well down the Appalachians. The northern pine forest occupied a large area in the Great Lakes region and smaller areas throughout most of the Northeast. It is estimated to have covered not less than I IO, Ooo square miles. But the softwood forests of the South covered 225, ooo square miles. Of the mixed sof twood and hardwood forests approximately 80,000 square niles was northern and 70,000 southern. 
The forests of the western United States, in striking contrast with those of the East, contain almost no hardwoods. They are also very much more exposed to destruction or damage by fire. From the standpoint of area the forest east of the Cascade and Sierra ranges, in which western yellow pine and Douglas fir are the overwhelmingly predominant species, hold first place; but in volume of timber they are surpassed by the giant forests of the North Pacific Coast. Heavy coniferous forests cover the western slopes of the Sierras. Fxcept in the far north the forests of the Rocky Mountain region are less heavy, with spruce, fir, and lodgepole pine at high elevations, Douglas fir and yellow pine lower down, and in the south a large amount of pinon-juniper forest at still lower elevations. This pinon-juniper forest also occurs extensively in the Great Basin. The original area of the Rocky Mountain forests, and also the present, may be put at I 20,000 square miles (exclusive of brush and chaparral). That of the Pacific Coast States forests was 12,5,000 square miles. The forests of the Northern Rocky Mountain region covered 6o,ooo square miles; of the central Rocky Mountain region, 30,000 square miles; of the great yellow pine region, still farther to the south, 30,000 square miles.

\section{THE ERA OF DESTRUCTION.}

The first task of the original colonists in seeking to secure a permanent foothold on the western continent was necessarily to push back the forest, in order to make room for themselves. They had to clear land in order to grow food. At the same time they began to make use of the vast reservoir of virgin timber which the ages had made ready for them. Not only did it furnish them with housing and fuel; it provided abundantly an easily workable material from which they conld fashion all kinds of articles which they needed in their daily life, and it gave them at once something to export in return for what they drew from the Old World. Thlus began the drain on the forest which from the most insignificant beginnings in the early sixteenth century was to expand for four hundred rears, while the era of destruction ran its unchecked course.

The pioneer naturally gives little thought to conserving the natural resources of a region in which his urgent problem is to make a living, conquer the wilderness, and get ahead. His first need is for capital, or equipment; and labor is almost equally at a premium. Iand and whatever the land furnishes are by comparison of very small account. Lavish use of forest resources was therefore bound to take place in a long period of exploitation.

Tet the early colonists were not without apprehension of a possible danger from forest destruction. They needed wood close at hand. It was not until after steam power became available in transportation that wood could be carried far by land without becoming very costly. The colonists lacked even wagon roads. Some of the settlements began 
to face the prospect of a local timber shortage within a few years of their founding.

It was the same situation which European toms had faced much earlier, and out of which had come the practice of forestry. In an age when wood was the only fuel in use it was a fundamental necessity of life to have a source of supply not far away, unless water transportation was practicable. Doubtless the solicitude evidenced by the restrictive measures which the colonists presently began to adopt was partly due to their background of Old-Morld ideas. Other restrictions were imposed on them by the mother country, with a view to monoplizing their trade and insuring to England ample supplies of naval stores, ship timbers, and masts. Thus early colonial history reveals a certain amount of attempted regulation of use of the forest, due to three distinct causes-actual diminution of the quantity of timber close enough to some of the settlements to meet their local requirements readily, old-IForld conceptions which the settlers brought with them, and restrictions imposed on them in the interests of the countries from which they came.

But the economic development of America could not be confined within the straight-jacket of artificial constraints. It took its own course along the lines made inevitable by the new environment. The forest resource on the fringe of which the colonists were establishing themselves was too vast to afford any real ground for restrictive measures. On the contrary, the task of the colonists was to fight the forest which hemmed them in, which sheitered wild beasts and wild men, which fought back at them for possession of their clearings, which was so huge as to make their assaults upon it seem puny and of negligible consequence. The threat of local shortages of timber was overcome by drawing on more distant supplies. Small sammills multiplied, and as they cut out the cream of what grew close about them many moved to new sites. Their product was rafted down the streams or loaded on ships, and commerce in lumber increased. The monopolistic regulations imposed iy the European colonial system were very galling, but were ineffective in the long run to prevent either the cutting of specified classes of trees or the expansion of trade along its natural lines. Forest exploitation provided the colonists with an ever augmenting stream of capital-their greatest need - at the same time that the steady warfare of civilized man against the forest conquered for him new ontposts and a widening domain.

Hostility to the forest became ingrained in the American spirit. To free the soil from its mastery was to serve the cause of progress, to create wealth, to help build an empire. Something of this spirit still survives in the newer regions, wherever agricultural expansion is taking place through the clearing of land now timbered. Within limits it was not merely natural and ineritable but justifiable. Only by forest destruction on a vast scale could transformation of the empty wilderness into the great commonwealths that occupy all the eastern part of the country, 
from the prairies to the ocean and from the Gulf to the Great Lakes, ever have taken place. But the zeal for ridding the land of forest growth to make room for agriculture has overshot its mark. A very large aggregate of cut-over land, some of which was farmed for a time, some of which has never been brought under the plow, is now nonproductive. That the community does not benefit, but suffers, when forests are destroyed and agriculture is introduced on land that it can not permanently hold is unfortunately too little realized. Such a course is either an economic and social blunder or a social crime. The history of land utilization in the United States affords abundant examples of both; and the chapter containing them is still unclosed.

\section{RISE AND COURSE OF THE LUMBER INDUSTRY.}

The first lumber of the settlers was rived or hewn from the log or sawed by hand. Within a very few years, however, water-driven or wind-driven sawmills were set up. The white pine of the Northeast was from the outset the main attraction; its lumber held far and away the leading place in quantity produced, down to the latter part of the nineteenth century. The qualities of the wood were such as to give it preeminence among the eastern softwoods for building and general uses. At the same time even the earliest of the colonists began to utilize for specialty purposes the hardwood growth-chiefly oak, which furnished ship timbers and staves. Pipe staves quickly became an important article of export.

Besides wood in several forms, the forest soon began to furnish for export naval stores, obtained from the resinous pines that grew in considerable abundance even in the northern colonies. The history of the naval stores industry in the United States parallels in many respects that of the lumber industry. It has, however, hitherto been confined wholly to the Liast and has long had its field exclusively in the southern States, where it has been carried on with methods so destructive that it is now rapidly declining and must soon sink to relative insignificance unless given a further lease of life through forestry.

All through the colonial period the advance of settlement inland was very slow. Generally, it followed the water courses. The lumber industry partly accompanied, partly preceded it. When the beginnings of a new community opened a clearing in the forest, a sawmill was as much a necessity as a gristmill. Sometimes the two were combined. On the other hand, the requirements of the growing older towns and the export trade created a market for lumber that caused supplies to be sought in the unbroken wilderness. Thus was developed the craft of the woodsman-lumberman. Its shifting camps and mills pressed farther and farther inland, while the spring freshets floated down the rivers its rafted product. In the rear of its operations the settlers gradually cleaned up the pine that was leit, and laboriously destroyed the hardwoods 


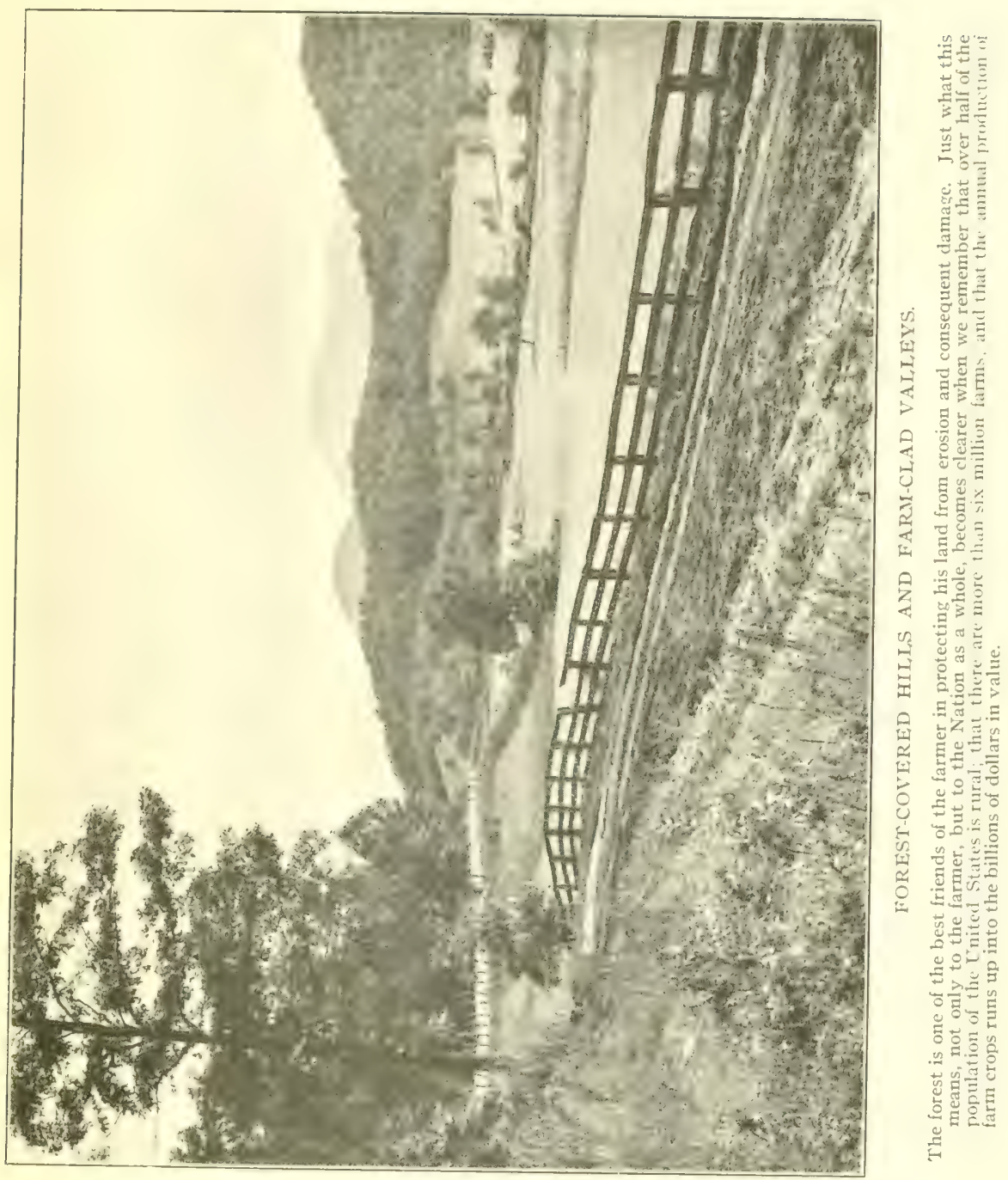



which had no value to them but were merely an incumbrance, to make room for their farms. So, toilsomely and painfully, the conquest of the wilderness proceeded.

Down to almost the middle of the nineteenth century the American lumber industry continued to be an industry of small and dispersed establishments, for the most part cutting merely to supply local needs, dependent on water for its motive power, with its technical processes still relatively primitive, and unable to distribute its product widely except as water transportation was available. Along the fall line, especially in northern New England, there developed some concentration of the industry, with larger establishments to which logs were brought downstream by "driving," and which supplied a broadening general market; yet Maine was the only State in which the cut much exceeded the consumption. Steam power began to be introduced as early as the beginning of the nineteenth century, but its use made little headway except where water power was not available and tended toward dispersal rather than concentration of production. The Eirie Canal, opened in I 825 , created an artery of commerce for the eastward movement of pine from western New York, and then from the Lake States, whose vast virgin supplies were also beginning to be tapped to meet the needs of the territory southward; but the population of the country was still relatively small and sparse, and the per capita consumption of lumber low in comparison with what it was shortly to become. After more than two hundred years of growth, the industry which had been born almost at the first landing of the colonists on the Atlantic Coast was still a stripling. It was swiftly to be transformed into a giant.

In I 840 the population of the United States was I7,000,000, and its per capita consumption of lumber is estimated to have been approximately 85 board feet. ${ }^{2}$ The period of rapid railway building and the profound changes in the economic and industrial life of the nation which it produced were about to begin. Settlement of the prairie States and the increased lumber consumption in the older regions due to higher standards of living and expanding industries, were to swell enormonsly the drain on the forests and bring in new methods of production. The Lake States pineries provided a virgin stand exceptional in accessilsility, quality, and volume. It was there that the American lumber industry was to find its great opportunity for transformation from a widely dispersed industry of small operations, slowly eating its way back alonis the water courses to the depths of the eastern forests, into a powerful engine of attack.

\footnotetext{
2 A board foot of lumber is 12 inches square and I inch thick; I 2 board feet are therefore the cquivalent of I cubic foot of lumber. In the United States it is customary to express the contents of logs and the stand of timber in the woods in terms of board feet; in that case the numerals mean the quantity of lumber which it is estimated can be manufactured, under the prevailing standards of utilization, from the given raw material. Since the amount of waste in manufacture varies with different sizes and classes of timber, and since the standard of utilization is not uniform, no single converting factor can be used to obtain the equivalent in cubic feet of board feet, log measure. For general purposes, however, eight board feet may be considered the equivalent of one cubic foot.
} 
At the mid century the population of the country had become 23,000,$\%$, and the per capita consumption of lumber 230 board feet. Yet New England, New York, and Pennsylvania still constituted the main producing region, with a cut that was over half that of the entire country: the average mill sawing and planing lumber still had an output valued at less than \$,3,300; and although nearly io,ooo miles of railway had been built, lumber transportation and distribution had been little affected. Twenty years later the trend of the times had become clearly evident. Michigan was the state of largest lumber production, and the arerage production per mill for the entire country had a value of over $\$ 8,000$. The railroad mileage of the country was more than five times as great as in I $\$ 5()$, while the capital invested in the lumber industry had risen irom Sfo, $(x),(x)(x)$ to oxer si $f(x, 0 x), 000$, and the value of the product had increased from less than $\$(x), 0(x),(x)$ to more than $\$ 210,000,000$. I:xpansion of preduction continned until igo6. In that peak year the cut was ft) billion board feet, the average production per mill had a value of over sit 4,000 , the capital invested in the lumber industry was over $\$ 1,0(x), 000$,ox, and the total value of all iorest products als: exceded that anomint.

Sixty vears, therefore, coner what may be called the heyday of exploitation. In this relatively short period leadership) in production passed suceessively from the Vortheast to the Iake states and the Sonth; while from rgo, onward the individual state with the largest output was IVashington. At the present time snuthern pine still remains the species furnishing the latrest cut, hut the three l'acific states produce almost as much lumber. wholly soltwoud, as the total of both softwouds and hardwoods in the eipht states of the sonthern group). Within less than the space of a single lifetime the center of prodlution has shifted from the . Itantic states to one great iorest region after another, and is now passing to the last region of all, on the opposite margin of the continent.

The lumber cut of the country in the entire colonial period could not have hegun to approach that of any individual year in the twentieth century. It was not in the days of stage-coach and frame-house towns, hut in these of the locometive and the sky-scraper that both total and per capita consumption reached its maximum. Since 1906, hovever, the trend of lumber production has been downward. In I920 it represented a per capita consumption of 316 board feet, as against.5(x) board feet in 1907 -a decrease of 37 per cent in $I_{3}$ years. The reason is not that the age of steel is making wood less wanted. hut that the cost of lumber is increasing. liniored economies have reluecl per capita consumption to about what it was in 1866 . The cost at the mill of each citizen's share of the lumber produced in 1920 was three times that in a soo, but its amount was one sixth less. The lumber industry grew to mighty proportions when the requirements of an adrancing and expanding Nation called upon it for rapid exploitation of the vast supplies of virgin timber that stood ready for use. As a purely exploitative 



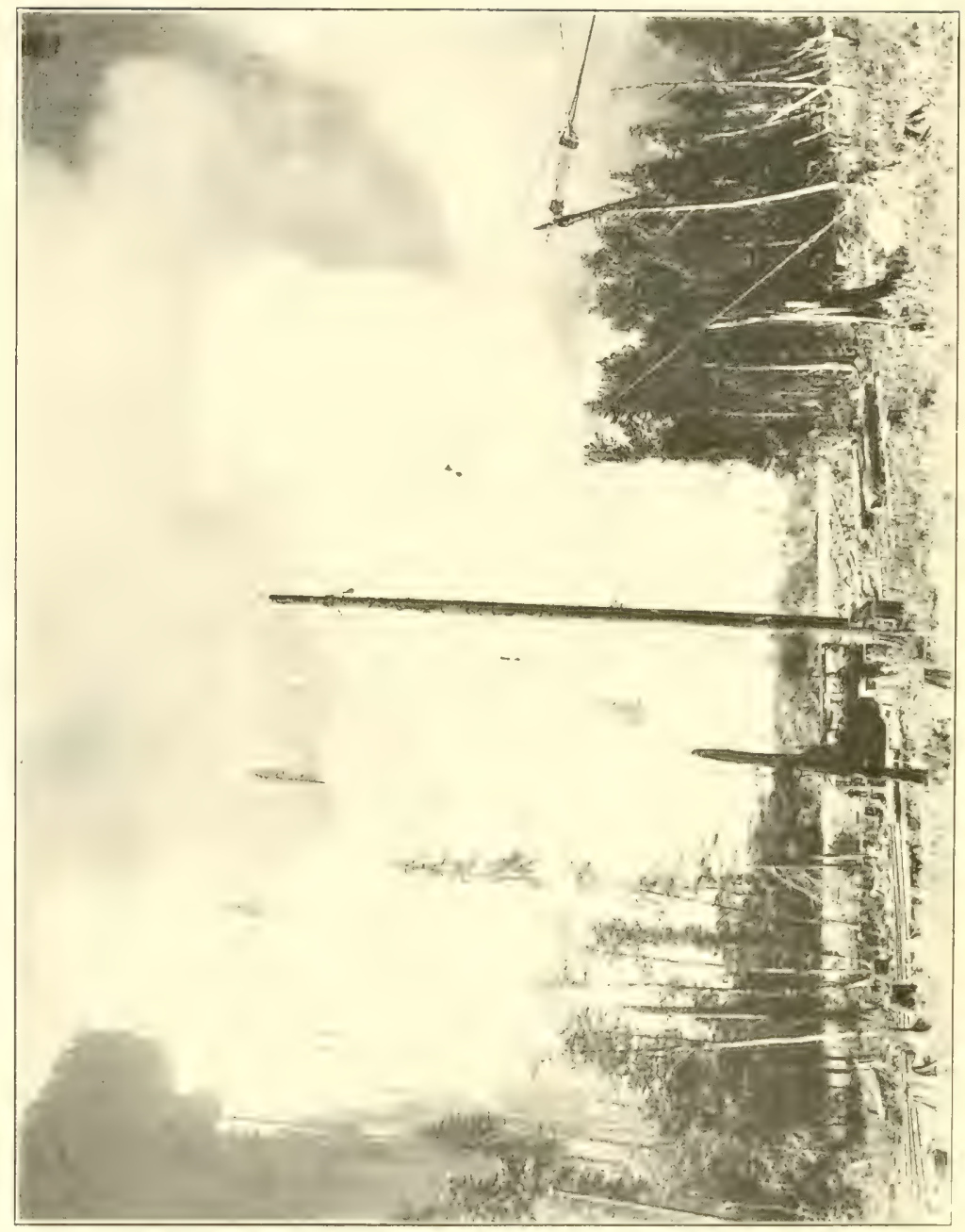

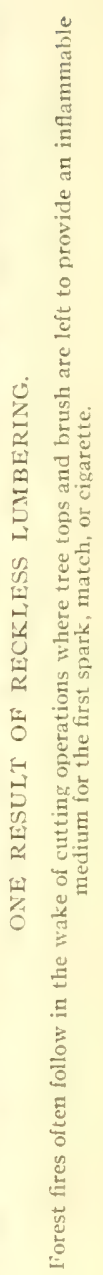


agency for the service of the public needs, it has nearly run its course. The declining consumption of lumber in recent years is a simptom that a new era is in sight, in which requirements must be adjusted to supplies obtained through the growing of timber.

While the lumber industry has been essentially migratory in its main course, with a shifting of the center of production from one great forest region to another, operations have continued in the older regions. This has tended to give a delusive effect of permanence. For a long time timber was so abundant that only the best was taken. Subsequently further utilization took place of what had been leit behind. The Northeast, for example, has never ceased to be the scene of lumbering operations, and its forests have been gone over again and again. It paid to return for trees of smaller sizes and for kinds of trees at first held in disesteem. As the rirgin white pine vanished from the stand, attention was turned to spruce in northern New Fingland, and hemilock in P'ennsyvania, as sources of supply of softwood lumber; and in course of time much second-growth reached merchantable size. But this continuance of the industry in the older regions is merely carrying depletion inther; the production of wood through growth does not balance the rate of use. 'Though the bulk of the country's lumber cut comes from the diminishing virgin forests, that which comes from the second growth exceeds the rate of replacement of this material. In addition, the second-growth forests are being drained in other ways than through cutting for conversion into lumber. It is estimated that the second growth under saw timber size is being used up three and one-half times as fast as it grows, while the second-growth saw timber is being cut one and one-half times as last as it grows.

In short, to support a permanent lumber industry, there must be a large forest capital in the form of growing stock, which must not undergo diminution if an even output is to be maintained. It is the progressive decline in the quantity of growing stock that carries the most serious threat to the future of the lumber industry. The cause of this decline is partly the cutting of timber without precautions to insure the establishment of a new crop of valuable trees; but by far the most serious cause is the damage done young growth by forest fires.

\section{FOREST FIRES AND THEIR CONSEQUENCES.}

Forest fires have been the chief agency in forest destruction and are the chief cause of forest depletion. Fire was the most effective tool of the settler for clearing land. It was also the inevitable aftermath of lumbering. As population increased in the forest regions, the number of fires increased. 'So long as timber was abundant these fires were lightly regarded or even held beneficial. I'ublic opinion inclined to the belief that in any case they were mpreventable; and until comparatively recent years no organized agency for combating them had been created. They have, therefore, for the most part had free rein. Iiven now a large 
part of the country lacks the most elementary provision for preventing and controlling forest fires, and adequate protection is given only a minor fraction of the total forest area.

Fires have destroyed an enormous total of merchantable timber, and have perhaps equaled if not exceeded in their toll taken from the virgin forests all that the lumbermen have cut for manufacture. There have been many great conflagrations that have destroyed everything in their path, with great losses not only of timber but also of other forms of property and of human life. But even more serious in the aggregate has been the damage done by the repeated burning of cut-over lands and by fires of minor proportions. After lumbering as customarily practiced, large amounts of inflammable material are left on the ground. When fire gets into this, as it usually does, the unmerchantable and young growth left by the logger is greatly diminished, if not wholly destroyed. Trees which the first fire kills without consuming furnish fuel in their turn for a later fire; and so the process goes on until the land is perhaps reduced to an unproductive waste, with even the soil robbed of all organic material or burned entirely away from the bare rocks.

Had it been possible to keep fires out of the woods, natural restocking would generally have replaced the timber by a new stand of reasonably satisfactory character, both in quality and amount. This would have been particularly true on the lands lumbered a generation or more ago before utilization became intensive. The lack of growing stock sufficiently advanced toward maturity to make good saw timber within the next forty or fifty years is the most serious element in the forest situation with which the United States is now faced.

In the forests of the West the danger of fires is far greater than in those of the East. A prolonged dry season each summer is the rule in these softwood forests. Their character makes them highly susceptible to damage, while their mountainous topography makes them hard to protect. Contending as they do with natural conditions generally far less favorable to tree growth than those found in the Eastern forest regions, they are much more easily destroyed. With increase of population and industrial activities, the fire hazard to which they are exposed tends to become greater and greater. Efficient protection of the forests of the West is absolutely necessary if they are not to be wiped out. Indeed, it is doubtful if the very best system of organized protection that can be maintained without a prohibitive cost can preserve them without the help of an enlightened and vigorous public sentiment that will make people careful not to cause fires. Fortunately, such a sentiment is developing. Had the opening up of the West gone on at the same time with that of the East, and had the attitude of the public toward the forest been the same, the original timber resources of the region would not be even a memory now.

Forest fires in the United States annually burn over an average of close to 17,000 square miles. Most of these fires run along the ground, 
fed by the surface litter or dry grass, and doing relatively little damage to the large trees, but killing mainly the seedlings and other young growth. Repeated fires of this kind result in a forest with an abnormal proportion of old trees, yet of decreasing density and quality. In extreme cases the forest may eventually be converted into worthless brush land or barren.

Primarily in consequence of forest fires much of the forest area of the United States has become partially or wholly unproductive. It is estimated that of the total area of approximately $72,3,000$ square miles, more than 126,000 square miles must be classed as idle waste, while about $3 s_{3,000}$ square miles is culled or cut-over land, of which only limited areas are fully restocking. The remaining virgin forest area of the country is about 214,000 square miles.

\section{THE FORESTRY MOVEMENT.}

Fears of a possible timber shortage and advocacy of limitations on the use of forests, and of the protection of forests against fire, have not been wanting in the United States from almost the first years of settlement of its eastern coast. The history not merely of agitation but of legislation. reaches back into the early colonial period. In the latter part of the eighteenth and early part of the nineteenth century sporadic cxamples of sentiment in faror of action to insure future supplies of timber cropped out. Between I799 and I83I several laws were enacted by Congress with a view to insuring supplies of live oak. But it was not until the latter half of the century that the movement for forestry in the Lnited States can be said really to have started. It followed close on the revolutionary changes in the lumber industry that began to take place around $\mathrm{I} 850$, and undoubtedly owed its origin to the accelerated rate of forest destruction that came as the Lake States pineries developed into an important field of operation.

In the late sixties official inquiries were inaugurated by several States, looking to the formulation of some conrse of action to protect their forest resources. Interest in timber culture through tree planting began to be manifest about the same time. To stimulate tree planting in the prairie country "Arbor day" was inaugurated in IS72. 'The next year the American Association for the Adrancement of Science made provision for submitting a memorial to Congress and the several State legislatures on the need for forest preservation and for recommending legislation. This eventually led to the inauguration of work in forestry by the Federal Government in 1876 , when a special agent was appointed in the Department of Agriculture to collect information.

Slowly the movenent gathered headway, receiving more and more support in public sentiment. In ISS I a Livision of Forestry was created in the Federal Department of Agriculture, and gradually expanded its investigations. In I89 I Congress authorized the President to create forest reserves from the timberlands of the public domain. 'This anthority was sparingly used until IS97, when I'resident Cleveland just before 
the close of his term of office proclaimed more than twenty million acres of new reserves.

This action was epoch making. It really inaugurated the policy of public ownership and operation of what are now known as "National Forests." Cp to that time the forests on the public domain seemed in a fair way to be destroyed eventually by fire and reckless cutting. Nothing was being done to protect them, or even to use them in the right way. They were simply left to burn, or else to pass by means of one or another of the land laws into the hands of private owners whose interest in most cases impelled them to take from the land what they could get easily and move on to other forested lands.

Had this destruction gone on unchecked, there would in the end have been little timber left in the western United States, either to burn or to cut. More than this, the destruction of the forest cover on the watersheds supplying hundreds of streams which rise in the western mountains would have had its certain effect on stream flow-low water or no water at all during the long dry periods, and destructive floods after heavy rains. This, of course, would have meant disaster to the systems of irrigation by which thousands of farmers raise their crops. It would also have very seriously hampered, and in many cases prevented, hydroelectric power development.

A few months after President Cleveland created the new forest reserves, Congress enacted a law outlining a system of organization and management for these public forests and placing their administration under the Secretary of the Interior.

Government administration of the reserves soon made apparent the necessity for scientific forestry to make their use general. It was the duty of the Secretary of the Interior to prescribe regulations which would insure the fulfillment of the objects aimed at in creating the reserves. 'Timber cutting must not destroy the forests, but must provide for the growing of a new timber crop. Grazing had grossly abused the range; it was necessary to devise methods for increasing the forage crop. Both timber use and grazing use must be so managed that water supplies would be maintained and bettered. All the resources of the forests needed to be given careful consideration and plans devised for their best development. Without such plans little of the value of the forests to the public could be secured. Technical problems were involved which the officials of the Interior Department felt to be outside their province. They therefore at first requested the aid of the experts of the Department of Agriculture as advisers, and soon recommended the transfer of administration of the reserves from the Department of the Interior to the Department of Agriculture.

This transfer took place in 1905 , and the forests were placed in charge of the Bureau of Forestry, into which the old Division of Forestry had by this time expanded. At the same time the name of the bureau was hanged to "Forest Service." 
To-day the forest work of the American Government is mainly centered in the Forest Service, which, in addition to administering and protecting the National Forests, studies a great number of general forest problems and diffuses information regarding forestry. The Government does other forest work, however, besides that of the Forest Service. 'The Department of the Interior, through its Office of Indian Afiairs and its National I'ark Service, administers the forests on Indian reservations and the national parks. The Office of Forest Pathology of the Bureau of Plant Industry, in the Department of Agriculture, studies the diseases of trees, and the branch of forest insect investigations in the Bureau of Entomology of the same department seeks means for controlling the insect enemies of the forests.

Long before the creation of National Forests began, virtually all the unreserved public lands in the States east of the Mississippi River had been taken up. Under the provisions of an act of March I, IgI I the so-called Weeks law), Congress inaugurated the purchase of mountain lands from private owners in the Appalachian and White Monntain regions of the East. Since this law was passed more than 2,000,000 acres of spruce and hardwood forest in the Eastern States have been acquired or approved for purchase, out of a total of more than 50,000,000 acres of this class of timberland upon which the eastern industrics have been dependent for their supply. The National Forest Reservation Commission, established by the act of March I, Ig I I, and consisting of the Secretary of War, the Secretary of the Interior, the Secretary of Agriculture, two Members of the Senate, and two Members of the Homse of Representatives, authorizes the purchase of all lands acquired under this act. As the Crovernment obtains title to these lands, the Forests are put 11nder systematic forest management with the object of improving their regulative effect upon stream flow and of increasing the supply of forest products.

The timber alone on the eastern National Forests has a present value greater than the entire cost to the Government of acquiring these lands, with their timber; and the revenue derived from these Forests has heen rapidly increasing until, in 1920 , they had become practically selfsupporting. Yet the sales of timber have hitherto heen salvaging operations or improvement cuttings rather than actual harvesting of what the Forests annually grow, for the lands had been depleted by lumbering and fires while they were in private ownership. Under the practice of forestry the stands of timber are increasing, at the same time that the protective value of the cover as a regulator of stream flow is materially improved. From an industrial standpoint, these eastern National Forests will play an important part as permanent sources of supply of material, particularly hardwoods for local wood-using industries, and will appreciably lessen the acuteness of the timber shortage in the East as the supplies of virgin timber approach exhaustion and hefore the seneral practice of forestry on private lands has been nuder way fong enough to supply timber of commercial size. 
Establishment of the National Forest system on an enduring basis was the chief task in forestry during the first fifteen years of the twentieth century. It involved not only the constructive development of a sound policy of administration but also the building up of an adequate organization and the winning of an approving public sentiment for what was to the people of the United States a novel and exceedingly dubious experiment in government. President Roosevelt gave the National Forest policy his most vigorous support, and included in the Fiorests most of the remaining public timberlands; during his administration the total area of the Forests was more than quadrupled. He also ardently championed conservation of the forest resources of the country generally, and greatly advanced the forestry movement.

Along with the building up of the National Forests and National Forest administration, there was being developed through research an increasing body of knowledge relating to forestry. In I9 ro the Forest Products Laboratory was established at Madison, Wis., in cooperation with the University of Wisconsin. This research institution has conducted a great number of studies by which knowledge of matters relating to forest products has been advanced along many lines. Forest experiment stations are also being developed.

Within very recent years the forward movement in forestry has been evidenced by a widespread interest in the questions of the further measures necessary to bring about the management of the private forest lands of the country in accordance with the principles of forestry. There has also been large progress in State forestry. Thirty-two of the states now have some organized provision for work in forestry, while 20 have State forests, with an aggregate area of over 9,ooo square miles. The Fiederal Government cooperates with 26 States for the protection of forests on the watersheds of navigable streams against fire, and is now appropriating $\$ 400,000$ annually for this purpose, while the State appropriations for cooperative forest protection are nearly \$2,000,000. About 259,000 square miles of forest land are now afforded protection in varying degree ninder the organized systems maintained by the States. The National Forests, protected by the Forest Service, have practically the same total area. Nevertheless, 40 per cent of the forest area of the country has no organized protection and 20 per cent has only nominal protection. With the great amount of forest land which is either restocking only partially or not restocking at all, and with the area of idle or largely idle land increasing at the rate of sone 6,000 square miles yearly, the stopping of forest fires is the inost urgent first requisite for increasing the future timber supply of the country. 


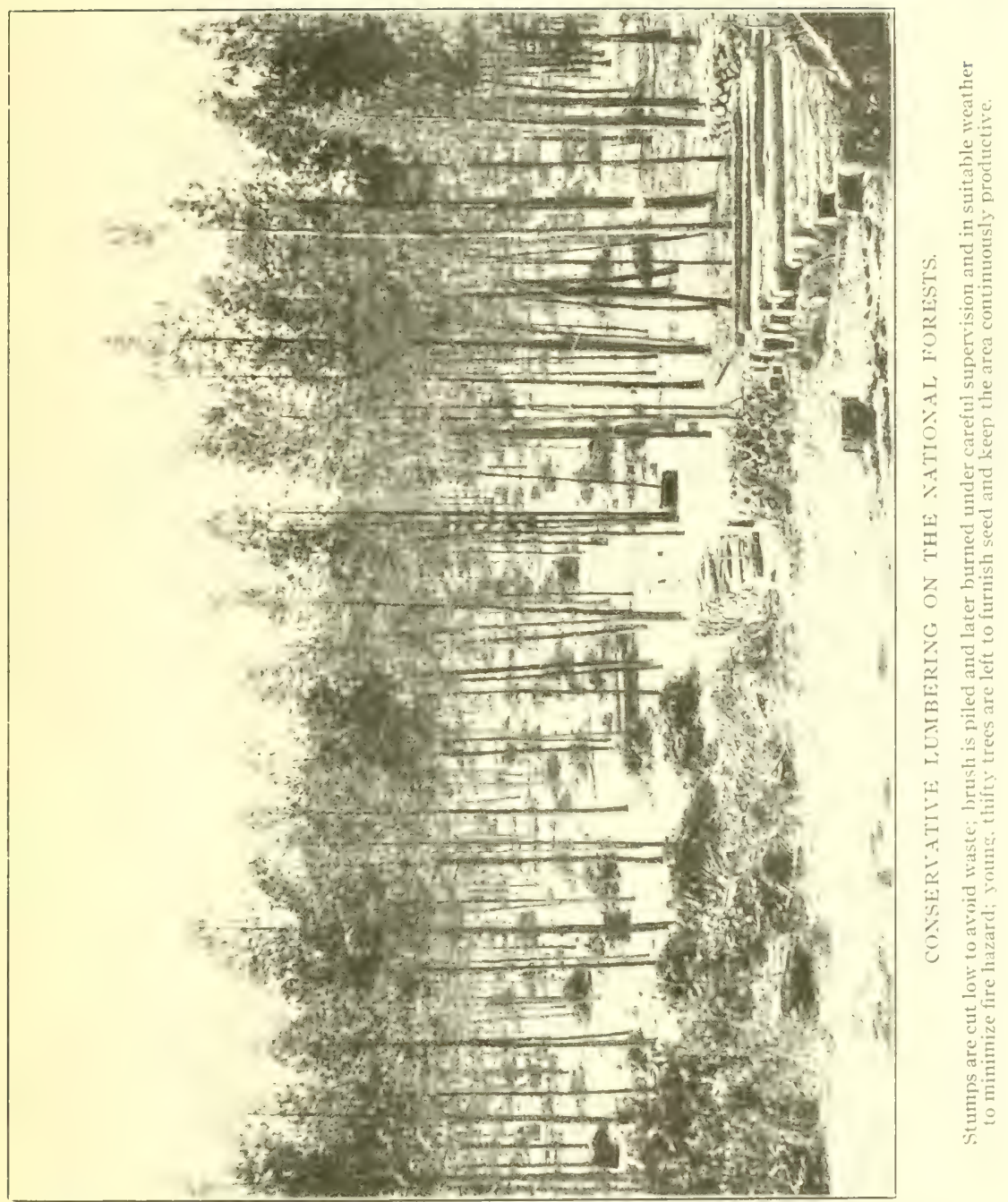




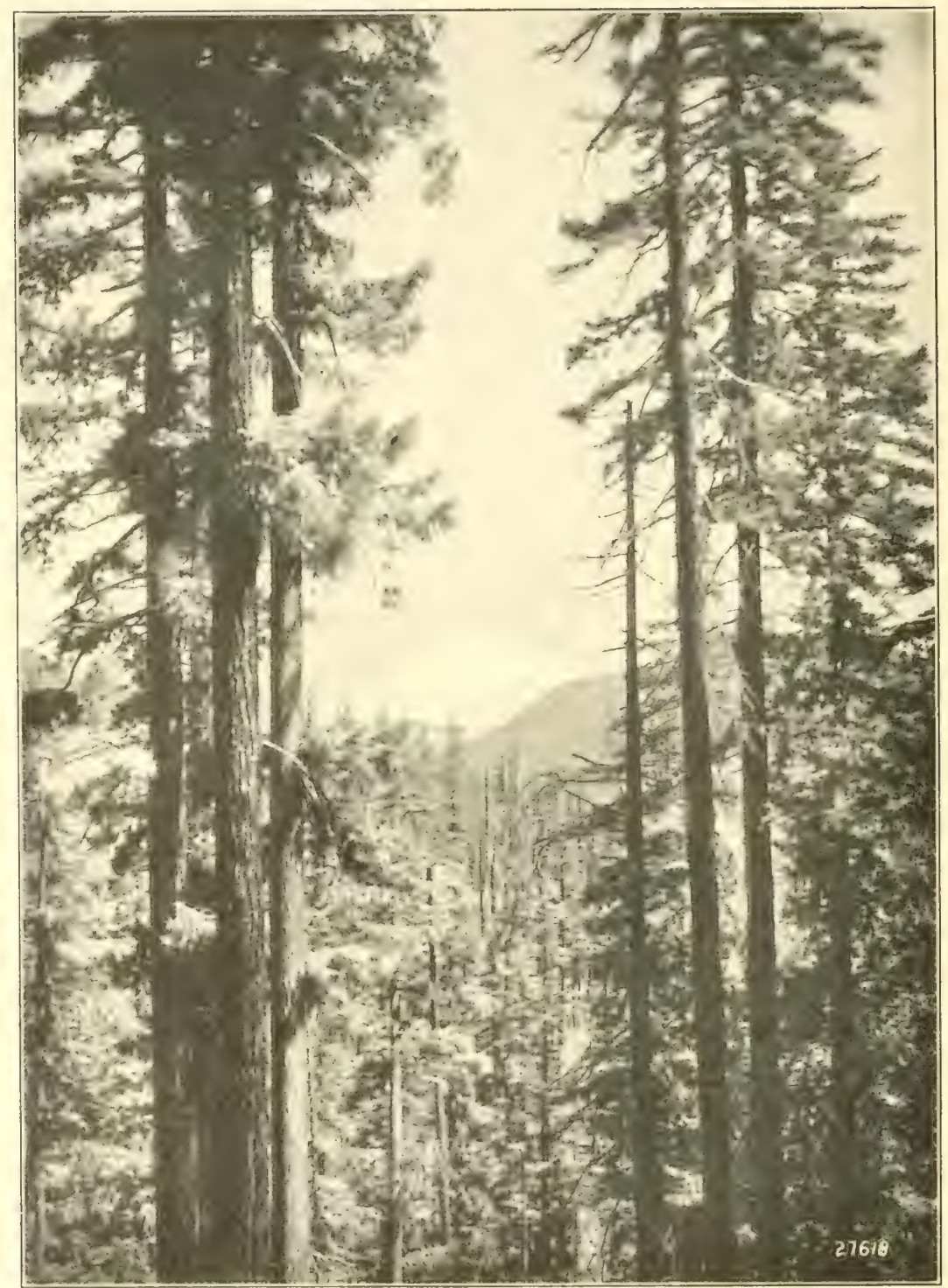

$16-2$ 
LIBRARY OF CONGRESS

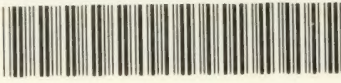

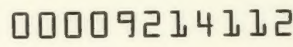

